postgraduate-level, and to include as much material as possible of a completely non-technological character. Although employers are still interested in the professional side of what the university does, most place the greatest emphasis on intellectual quality rather than on technical expertise.

There are a number of reasons for this. In the first place, as the rate of scientific and technological progress quickened, the need for people to be adaptable, quick to learn, and capable of covering a wide field has increased. It is no good giving a man a complete specialized training if what he has specialized in is obsolete before he has reached the age of thirty.

Secondly, a large proportion of university graduates do not in fact do the job for which officially they were trained for more than a quite small proportion of their careers. Finally, as industrial concerns get larger and the place of industry in the national life increases in importance, the scope of the decisions to be taken by industry become even wider, reaching far beyond the boundaries of straightforward technical questions.

There is a fruitful field for active collaboration between the universities and industry. Many students already go to industry for vacation courses. It should be possible to relate what is done in industry much more closely to the academic side than had been done in the past. It might be possible for undergraduates and even more for postgraduates to do part of their 'course work' as an investigation of some industrial problem 'in the field'. The 'sandwich courses' in the colleges of advanced technology may prove to be the pioneers in this field.

But, no matter how good an understanding is achieved between education and industry, and no matter how courses are adjusted to meet contemporary needs, education cannot be thought of as a process which finishes in the early twenties. Some sabbatical period is as essential for men in industry as in the universities. Specialized postgraduate courses on technical subjects for people released from industry are becoming commoner and better supported. The universities and particularly the faculties of science and technology must be prepared to organize more of these courses.

Advanced technical work is not the most important purpose for which industry requires its own 'sabbatical years'. There is a stage at which intellectual renewal is particularly valuable, the stage when a man emerges from a relatively specialized department and begins to take managerial responsibility over a wider field; by that time, he has enough experience to be able to appreciate what the problems of management actually are, but usually scarcely any systematio knowledge of how they have been mastered.

Education in management in Great Britain lags a long way behind that in the United States; this is a matter to which the universities must give much more serious attention. By far the greatest difficulty is the recruiting of suitable staff. Management is essentially a practical subject, and the man who is good at it wants to practise and not to instruct.

A managerial or business school recruiting 'students' from a wide variety of industries would be better than one run by one undertaking, no matter how large; this end can perhaps be most directly achieved by co-operation between the great companies in founding their own institutions rather than by working through the existing university structure.

\title{
TRAINING IN RADIOLOGICAL HEALTH AND SAFETY
}

$\mathrm{O}$ $\mathrm{N}$ the night of October 10,1957 , the core of No. 1 reactor at the Atomic Energy Authority works at Windscale became seriously over-heated and as a consequence a fairly large amount of radioactive material escaped through the reactor stack and was deposited thinly over many square miles of northwest England. Once the alarm was given, the Health and Safety Services of the Authority went into action on their first major emergency test. Fortunately no significant harm was done to the populations of the surrounding areas, although the affair naturally received widespread publicity.

By now the 'Windscale incident' has almost passed into history, but it is interesting to find unexpected repercussions almost three years later. Following the accident, the Prime Minister set up a Committee under Sir Alexander Fleck to report, among other things, on the organization for control of health and safety in the United Kingdom Atomic Energy Authority. The report of this Committee directed attention to the serious shortage of trained radiological health and safety specialists and called for comprehensive schemes of instruction in this field as a "matter of urgent national importance". The Fleck Committee firmly placed the onus of leading the build-up of a national supply of specialists on the Atomic Energy Authority. In view of this, the Authority set up a further Committee under Sir Douglas Veale to consider what steps should be taken to provide a staff concerned with health and safety for the Authority, and for the nation as a whole, including the establishment of a national training centre*.

Although now a matter of extensive public concern, radiological health and safety are by no means a new problem. The hazards to man of ionizing radiations have been known since the early years of the century, and the distressing experiences of the early radiological workers have kept the matter well to the fore in the minds of their successors. In 1921 the first concerted effort to deal with the problem came with the publication of the first Recommendations of the British Committee for Radiological Protection. This was quickly followed by other national recommen. dations and by the Recommendations of the Inter. national Commission; the latter, revised from time to time, still form the basis of world-wide radiological protection measures. Until 1945, radiological safety was a matter of concern limited almost entirely to medical radiologists and a handful of physicists attached to hospitals and medical schools. The development of nuclear reactors and weapons changed. the whole picture. Production and uses of ionizing radiations have increased enormously, the number of persons occupationally exposed has increased correspondingly, and we are now faced with the position * Report of the Committec on Training in Health and Safety to
the Authority Committee on Health and Safety, United Kingdom Atomic Energy Authority, February 1960. Pp. vi +95. (London: 
that, to a greater or less degree, whole populations are at some hazard. The number of hospital physicists has increased and the atomic energy industry has recruited considerable staffs for health and safety work, but it is clear that further recruitment and the provision of specialized training are necessary if the inevitable hazards of ionizing radiations are to be kept to a minimum.

The Veale Committee estimates that in the present decade, Britain's needs will be met by recruiting and training some 500 staff at graduate level and 600 at technical level. These are modest enough figures, but they nevertheless represent a further demand on the country's already strained resources of scientific man-power. Of the graduate group, 200 are placed in Category $A$, with a requirement of good degrees in science, medicine or engineering and capacity to assume higher managerial responsibilities and play a leading part in scientific dovclopment. The recruitment of this category is likely to prove the most difficult. Establishment of a national training centre is rightly rejected by the Voale Committee and it is proposed the postgraduato training should be limited to a small number of university centres, using the normal advanced courso and research studentships of the Dopartment of Scientific and Industrial Rescarch to support the trainoes. This is probably a wise recommendation. Novertheless, as a balanced radiological health and safety force requires primary qualifications in physics, chemistry, ongineering, biology or medieine, considorable pressure will be required to overcome the blandishments of lucrative industry and professions and the temptations to do postgraduate research in the appropriate department of tho young graduate's alma mater. A high level of altruism may be necessary if a well-qualified medical graduate is to accept the rigours of a Department of scientific and Industrial Research studentship in an almost alien subject, in order to qualify in radiological health and safety.

The recruitment problem in the rather lower graduate category and in the technical grade, though not easy, should not prove insuperable. The Committee goes well beyond the question of recruitment and training of full-time health and safety staff. Recommendations are made on background training for groups of administrators, managers and professional workers whose duties may bring them into contact with radiations and radiation workers. Many other groups, varying from medical officers of health and general practitioners to public health inspectors, police and fire services and nurses, are likely to be increasingly involved in radiation problems, and wide dissemination of knowledge of radiation hazards and protection at a fairly elementary level becomes essential.

In some of the appondixes to the report, outlines are given of existing or proposed training curricula at levels ranging from a Ph.D. course to simple background courses. It is clear that if recruitment is satisfactory, adequate training can be made available. Eyebrows may, however, be raised in some university boards of studies at the proposal that some Ph.D. courses should be converted from the traditional British research pattern to the American form, including a high proportion of formal teaching and examinations.

Ionizing radiations have become a major and ubiquitous factor in modern life, and, as with other developments, they bring thoir own hazards. The vigorous implementation of the report could go a long way towards establishing public confidence that the hazards, which to many are strango and unseen, are kept within the limits which might reasonably be accepted in a rapidly developing eivilized community.

J. E. ROBERTS

\section{LOCALIZATION BY AUTORADIOGRAPHY AT - $195^{\circ} \mathrm{C}$. OF RADIO- ACTIVE AREAS IN RATS EXPOSED TO A HIGH FLUX OF THERMAL NEUTRONS: IMPORTANCE OF PHOSPHORUS-32 IN CONSECUTIVE INTERNAL IRRADIATION}

\section{BY JEAN CHANTEUR and PIERRE PELLERIN}

Institut National d'Hygiène, Service Central de Protection contre les Rayonnements, B.P. 30, Chatillon-sousBagneux, Seine

$\mathrm{T}$ HE purpose of this present work was to localize the organs or areas of the body of a mammal capable of becoming the seat of a radioactivity induced by exposure to a flux of thermal noutrons. Autoradiography at the temperature of liquid nitrogen $^{1}$ seemed to us to be the simplest and speediest method of carrying out this localization by applying it to a young rat.

A preliminary calculation has enabled us to fix in 5 min. the duration during which such rats should be subjected to a flux of thermal neutrons $\left(6 \times 10^{12} \mathrm{n} . / \mathrm{cm} .{ }^{2} /\right.$ sec.) which we had available in a large nuclear reactor so that we could both makc an autoradiographic exposure in an acceptable time, and not reach an activity of the block that might be dangerous for the operators. (Wo thank the Service of Biology and the Exploitation Service $E L 3$ at Saclay which placed suitable irradiation means at our disposal for bringing this experiment to a successful conclusion.)
Rats weighing $25 \mathrm{gm}$. were placed alive, in pairs, in plastic irradiation cartridges, and the latter were convoyed by pneumatic tube to the irradiation holes of the reactor.

After 5-min. irradiation, the cartridges were removed from the reactor. We ascortained that the rats had been killed by the flux of neutrons, and that in the oxposure conditions just described the doso-rate at $10 \mathrm{~cm}$. from the cartridge containing the two rats was about 1 roentgen $/ \mathrm{hr}$. at the exit from the pneumatic tube.

With tho usual precautions required by this doserate (screens, lead containers, remote control, etc.) we immediately proceeded to freeze the rats in liquid nitrogen $\left(-195^{\circ}\right.$ C. $)$, including them in the frozen mixture of water and alcohol, then counter-sinking the autoradiography plan according to the technique previously described by one of $\mathrm{us}^{1}$. 